Scott Donaldson

\title{
A Death in Hollywood: F. Scott Fitzgerald Remembered
}

F. SCOTT FITZGERALD spent the last three and a half years of his life in Hollywood, but he never really belonged there. His secretary, Frances Kroll Ring, recalls seeing him walking to Schwab's drug store on Sunset Boulevard, wearing a dark topcoat, a gray homburg, an indoor pallor, and looking for all the world as if he'd just got off the train.

Fitzgerald came west midway through 1937 to write for the movies and make enough money to keep his wife Zelda in the best sanitariums and his daughter Scottie in the best girls' prep schools. He worked hard at learning the craft- "he didn't just take his $\$ 1,500$ a week and run," his young colleague Budd Schulberg said-but Fitzgerald and Hollywood were the wrong mix. His scripts were not filmed, and he drank himself into trouble on the job.

By 1940 the big studio money had disappeared, yet Scott Fitzgerald's future looked better than it had in years. He had the love and support of Sheilah Graham, the beautiful former English showgirl who was making a success as a Hollywood columnist. His drinking had subsided, almost entirely. Best of all, he was at work on a novel, The Last Tycoon, that promised to convert his Hollywood experience into fiction. And fiction, of course, was what he was born to write. Although he had a lot of trouble sleeping, was easily distracted by noise, and was addicted to Raleighs and Coca-Cola, Fitzgerald was not at all unhappy when, late in November 1940, he took one of his walks to Schwab's for ice cream and suffered his first serious cardiac spasm.

The attack was severe enough so that he moved the one block from his third floor apartment at 1403 North Laurel to Sheilah's ground floor apartment at 1443 North Hayworth. (Appearances counted for something in the Hollywood of 1940.) But he did not stay in bed, as his doctor had advised. Instead he continued to work on The Last Tycoon. On December 20 he managed to complete a difficult episode, and he and Sheilah celebrated by going to a press preview of This Thing Called Love, starring Rosalind Russell and Melvyn Douglas. When the film was over and Fitzgerald 
tried to stand up, he had to grab the arm rest for support. It was just like Schwab's, he told Sheilah; all at once, everything started to go. Then he felt better, and since his doctor was supposed to come by the next day, they decided not to call him.

The accounts of the two people who saw Scott Fitzgerald alive on December 21, 1940, the Saturday before Christmas, tell us something about the capriciousness of memory. Scott slept well during the night, according to Sheilah; he slept fitfully, according to Frances Kroll Ring. The day was bright and sunny, Sheilah recalled; it was cool and overcast, Frances remembered. Scott was wearing slacks, slippers, and a sweater over his shirt, Sheilah wrote; he was wearing tan slacks and a plaid jacket, Frances reported.

Frances stopped by late in the morning to drop off some typed manuscript pages and bring Scott his mail. Only Sheilah was with him when the massive heart attack struck. She and Scott had lunch together, and then he settled down in her green armchair to read the Princeton Alumni Weekly while waiting for the doctor's visit. She gave him two Hershey bars for his raging sweet tooth. The last time their eyes met, he sheepishly looked up from making notes on the Princeton football team to lick the chocolate from his fingers. A few moments later, he rose from his chair as if yanked by an invisible cord, grabbed at the mantelpiece, and crumpled to the floor. By the time the Pulmotor arrived, he was dead.

At the time of his death at forty-four, Fitzgerald's reputation was at its nadir. If people thought of him at all, it was as a back number-a Jazz Age writer time had passed by. Scribner's had six of his books in the warehouse, but hardly anyone was buying them. His last royalty check, in August 1940, was for the unlucky number of $\$ 13.13$, and represented sales of forty copies. Most of those copies he'd bought himself.

His body was laid out for viewing in the William Wordsworth room of a downtown Los Angeles mortuary. Few people bothered to come. One who did reported that not a line showed on his face and none of his hair was gray. He looked "like an A production in peace and security," except for the thin and terribly wrinkled hands. "The poor son of a bitch," Dorothy Parker is supposed to have said.

The memorial service, held back in Maryland, was attended by about thirty people. Zelda was absent for reasons of illness, Sheilah for reasons of propriety. Because Fitzgerald was not a practicing Catholic and had 
received neither extreme unction before his death nor conditional absolution immediately afterwards, the church authorities in Maryland would not allow him to be buried alongside his parents in the cemetery of St. Mary's Church in Rockville. Ten years earlier, he had seen his father laid to rest among his ancestors in that cemetery, and thought to himself how "very friendly" it was to leave him there "with all his relations around him." In death, he could not join that company. He was buried instead in Rockville Union Cemetery, two miles from St. Mary's. Zelda's remains were laid at his side in March 1948, after her death in a fire at Highland hospital, in Asheville, North Carolina. "Time seems of less relevance every day," she wrote in her last letter to her mother. And yet time has changed almost everything.

The Fitzgerald revival makes a remarkable chapter in the history of literary reputation. Begun in the 1940s under the stewardship of fellow Princetonian Edmund Wilson, interest in Fitzgerald took a giant leap with the publication of Schulberg's novel The Disenchanted (1950), whose alcoholic screenwriting hero was "70 per cent" modeled on Fitzgerald, and of Arthur Mizener's groundbreaking biography The Far Side of Paradise (1951).

For many, the tragic story of Scott and Zelda-reckless, flaming youths who partied hard in the 1920s and crashed and burned in the 1930sacquired the luster of a legend. Finally, though, F. Scott Fitzgerald's writing has outlasted even that legend. Today the books that were very nearly unavailable fifty years ago are selling at a rate of 500,000 copies a year.

Scottie Fitzgerald Smith, the Fitzgeralds' only child, found herself in mid-life both the considerable beneficiary of her father's success and the uneasy caretaker of her parents' position in the literary and social history of the United States. "I am bewildered by what they have come to mean to so many people, both together and separately," she wrote me in November 1980. Some of it was wonderful, and some of it - the cultist worship of Scott and Zelda as fallen idols-was "not so good." Young people glamorized their collapse, and even sought to emulate it. They wore Jazz Age clothes, drank too much, and swam through their days in a Fitzgeraldian haze. Terrible movies were made from his books. In the wake of the disastrous Robert Redford film of The Great Gatsby, bars called "Gatsby's" sprang up everywhere. In 1978 Scottie and I had a drink at one of these, in Washington, D.C., where something that smelled exactly like marijuana issued from the air conditioning vents. 
Troubled as her parents' lives had been during her childhood, Scottie never felt unloved. After her mother's breakdown in 1930, Scott had more or less assumed the role of both parents. Feeling the dual responsibility, he was excessively stern with his daughter. "What are you trying to do? Alienate her forever?" Sheilah asked him after reading one particularly brutal letter he was about to send Scottie. Sometimes he embarrassed her when he was drinking. Once, in an alcoholic rage, he sailed an inkwell by her ear. But he was not himself then, Scottie believed: liquor made him into a different person entirely. So she forgave him those lapses as she forgave the lectures he delivered through the U.S. mails.

An extremely able guardian of her father's literary reputation, Scottie was never prouder of anything than of moving Scott and Zelda's graves to St. Mary's cemetery. With the aid of the Rockville Women's Club and a young priest "who couldn't have cared less about the doctrine of the thing," her parents were reburied there in a simple, moving ceremony in November 1975. Shouting over the roar of the traffic, noted Fitzgerald scholar Matthew J. Bruccoli read briefly from the author's novels and letters. "I belong here," he quoted from one letter, "where everything is civilized and gay and rotted and polite. And I wouldn't mind a bit if in a few years Zelda and I could snuggle up together under a stone in some old graveyard." It took 35 years to happen, and St. Mary's cemetery is completely surrounded by highways and high-rises, but, as Scottie wrote, "at least he's there with his parents and grandparents and other relatives from the Old Maryland he loved."

Scottie herself is gone now-she died in June 1986-and so is Sheilah, who passed away in November 1988. Among survivors, Honoria Murphy Donnelly's recollections stretch back furthest in time. The daughter of Sara and Gerald Murphy, whose own tragic tale has taken on the aura of romance, Honoria was a little girl when Scott and Zelda used to visit her parents on the Riviera, in the middle 1920s. She looked forward to those evenings, for Scott would sit down on the floor to talk to the children and to ask them questions.

"What is your favorite color?" he asked Honoria.

She knew the answer to that one. "Red," she said. "It's red."

"Why do you like red?" he wanted to know.

She hadn't thought about it, but supposed it had something to do with flowers. 
The more he had to drink, the more penetrating Scott's questions became. Honoria did not mind at all. He always seemed interested in what she thought, and he really listened to what she had to say.

Zelda she recalls as beautiful, very blond against her tan, in a pink dress with a peony at the shoulder. Then Honoria's memory fast-forwards to tea with Scottie and Zelda twenty years later, in 1947. After many years of institutionalization, Zelda wore her hair in severe bangs, and her expression was troubled. Once she had been the gayest person alive, now she could barely make conversation. Sara said something about Ernest Hemingway, and Zelda looked blank.

"Don't you remember Ernest?" Sara asked.

"I don't think so," Zelda said. "I can't remember that person."

That was a poignant moment, but the Murphys had their own sorrows. Both of Honoria's brothers died in their youth, Patrick after a seven-year siege with tuberculosis. When the end came for Patrick, it was Scott's letter that most comforted Sara Murphy. "The golden bowl is broken, indeed, but it was golden," he wrote her. "Nothing can ever take those boys away from you now."

The son of a Hollywood producer, Budd Schulberg was fresh out of Dartmouth in 1938 when he was assigned to team up with Fitzgerald for a script on his alma mater's winter carnival. On location at the college, Scott fell off the wagon precipitously, and Walter Wanger fired him. Other scriptwriters were called in, and Winter Carnival (1939), starring Ann Sheridan and Richard Carlson, was stitched together out of their joint efforts. The film is "pretty bad," Schulberg says, "so bad that it's almost good." It's still shown during the Dartmouth winter carnival, for undergraduates to hoot at.

What most struck Budd about Fitzgerald was his enthusiasm for ideas. Together they debated into the night about politics and books, and Scott pumped Budd for inside information on Hollywood and the brilliant Irving Thalberg. Much of what Fitzgerald learned from Budd went into his depiction of Monroe Stahr in The Last Tycoon, published posthumously in 1941. Much of what Schulberg discovered about Scott went into his portrayal of Manley Halliday, in The Disenchanted (1950).

Nowadays Schulberg keeps a copy of Tender is the Night in his study, and often opens it at random and starts reading. "I love to read that book," he says. One reason is the beauty of the writing, but there's more to it 
than that. In Tender, "Scott was able to take his own pain and suffering and transmute it into literature, and that's awfully hard to do." It required objectivity to deal with the emotion, and subjectivity to keep the feeling powerful. And it required courage, too.

Fitzgerald's spirit helped shape the career of yet another child of Hollywood, Sheilah's daughter Wendy. Born some years after Fitzgerald's death, Wendy grew up in a fatherless household. "Our only father was the ghost of F. Scott Fitzgerald," she recalls, and this was especially true as her mother relived her affair with Scott in the pages of Beloved Infidel (1958) and College of One (1966). For Wendy, the most important gift Fitzgerald left behind were the books her mother read under his tutelage, her "College of One" library. As an awkward, intense teenager, she found escape in the pages of Bleak House and Tom Jones, Sister Carrie and The Brothers Karamazov. Eventually she took her doctorate in English literature and became a college professor and dean-a career about as different from her mother's gossip columning as could be imagined.

Fitzgerald's influence on later American writing has been pervasive. Some have tended to identify with him. John Cheever, who volunteered to write the entry on Fitzgerald for Atlantic Brief Lives, praised and condemned him there for exactly those qualities that were as much his own as his subject's. In Fitzgerald's fiction, Cheever pointed out, "there is a thrilling sense of knowing exactly where one is-the city, the resort, the hotel, the decade and the time of the day." He did not write mere vignettes "but real stories with characters, invention, scenery and moral conviction." And yet he was personally subject to "appalling lapses in discipline," to "pranks, pratfalls and ghastly jokes." All of those observations apply to Cheever as well as to Fitzgerald.

For many of today's best writers, The Great Gatsby serves as a kind of touchstone. Joan Didion reads the novel over and over again. "It's one of the three perfect books I go back to, along with [Ford Madox Ford's] The Good Soldier and [Joseph Conrad's] Victory." She first read Gatsby in high school, in Sacramento, California, but it didn't mean as much to her then as it later came to. "I didn't know enough," she pointed out. "To really understand the book, you have to know about the east, about what it means to buck up against the east."

Allan Gurganus, author of 1989's best-selling Oldest Living Confederate Widow Tells All, undertook an exhausting tour of thirty-three cities to 
promote his novel. To make the trip less wearing, he promised himself a treat when he finally got back home: he sat down and read The Great Gatsby straight through. "It's one of the great American novels," Gurganus says, and it usefully reminded him that good writing has nothing to do with book signings and talk shows.

In one of the poems in Westward (1990), Amy Clampitt focuses on the unprepossessing figure of Henry C. Gatz, Gatsby's father,

An old man bundled into a long ulster

who'd telegraphed and then taken the day coach from somewhere in Minnesota ...

to attend his son's funeral, only to be "seduced out of his grief" by the splendor of his mansion. Herself a native Iowan, Clampitt was also moved by the passage in Gatsby about returning from the east at Christmastime to Chicago and then to Minneapolis-St. Paul, where Fitzgerald captures the promise and mystery of that snowy landscape:

That's my Middle West - not the wheat or the prairies or the lost Swede towns, but the thrilling returning trains of my youth, and the street lamps and sleigh bells in the frosty dark and the shadows of holly wreaths thrown by lighted windows on the snow.

She bought her copy of Gatsby in the 1940s "before the Fitzgerald boom." It became an important book for her, "one that does not fade with rereading."

Tobias Wolff, who won the 1985 PEN/Faulkner award for The Barracks Thief, continues to read Fitzgerald "with astonishment and love." The astonishment derives not only from the beautifully sculpted prose, but from Fitzgerald's uncanny ability to speak to readers across the generations. "He saw our American world-and I don't mean the historical country, but the contemporary United States, for he is our contemporary and what he wrote about has not gone away-with clearer eyes than any of his contemporaries."

In his fiction, Wolff believes, Fitzgerald portrayed "the entanglements of class, the situation of the outsider, the need for self-invention, and 
above all the great ruling paradox of American life: on the one hand the endless sense of possibility, on the other the lack of any stable identity or place where one belongs." Lacking that anchor, his characters sometimes drift into a romanticism that can become corrupt, as it did for Gatsby.

Their romantic quest has a powerful appeal, but when it ends in disillusionment or death-for in Fitzgerald the diamond mountains blow up and true love does not last-we are left to reflect on how and why the dream went wrong. The stories and the people we do not forget, for they are real. 